\title{
ANALISIS PERBANDINGAN JUMLAH ALAT BERAT DENGAN PENERIMAAN PEMUNGUTAN PAJAK DARI TAHUN KE TAHUN DAN KONTRIBUSINYA DALAM MENINGKATKAN PENDAPATAN ASLI DAERAH SULAWESI UTARA
}

\author{
Hana Glorya Karels ${ }^{1}$, Herman Karamoy $^{2}$, Meily Y. B. Kalalo ${ }^{3}$ \\ 1, 2, 3 Jurusan Akuntansi, Fakultas Ekonomi dan Bisnis, Universitas Sam Ratulangi, J1. Kampus Bahu, Manado, \\ 95115, Indonesia \\ E-mail: gloryhana7@gmail.com
}

\begin{abstract}
Local governments always need local revenue sources that can support regional expenditure financing from various alternative revenue sources that may be collected by the region. Tax as the biggest source of state revenue has a tendency to increase from year to year. One of them is the motor vehicle tax, especially the heavy vehicle motor vehicle tax. The purpose of this study is to analyze the magnitude of the comparison of the number of heavy equipment from year to year with existing tax revenue, analyze its contribution in increasing local revenue and the obstacles faced in heavy equipment tax collection in North Sulawesi using descriptive qualitative research methods. Research results show that the number of heavy equipment that exists with the amount that pays heavy equipment tax has an unbalanced comparison from year to year. With an average number of revenues or tax realization of heavy equipment in the last 3 (three) years amounting to Rp. 198,250,854. The average heavy equipment tax contribution from 2016 to 2018 is only 0.18\%, which shows very poor criteria. The existence of a lawsuit from the association of owners and users of heavy equipment that is still in the process of being one of the obstacles of collecting heavy equipment tax itself. Keywords: regional original revenue; heavy equipment tax; comparison; contribution
\end{abstract}

\section{PENDAHULUAN}

Pembiayaan pemerintah daerah dalam melaksanakan tugas pemerintah dan pembangunan senantiasa memerlukan sumber penerimaan yang dapat diandalkan, kebutuhan ini semakin dirasakan oleh daerah terutama sejak diberlakukannya otonomi daerah di Indonesia, yaitu mulai tanggal 1 Januari 2001 (Darwin, 2010:4). Otonomi daerah adalah hak wewenang dan kewajiban daerah otonom untuk mengatur dan mengurus diri sendiri urusan pemerintahan dan kepentingan masyarakat setempat sesuai dengan peraturan perundangundangan (Wulandari dan Iryanie, 2018:1). Menurut Santoso (2020), otonomi daerah memberikan peluang bagi daerah untuk menggali potensi-potensi yang ada sehingga mampu mandiri dalam hal keuangan. Berdasarkan Undang-Undang Nomor 33 Tahun 2004 tentang perimbangan keuangan antara pusat dan daerah pasal 1 angka 18 menyatakan Pendapatan Asli Daerah (PAD) adalah pendapatan yang dipungut berdasarkan peraturan daerah sesuai dengan peraturan perundang-undangan. Salah satu potensi daerah adalah pajak daerah, yang dapat digunakan sebagai sumber pembiayaan pembangunan daerah, namun masih tedapat kendala dalam hal masih rendahnya kesadaran membayar pajak (Buntuan dan Wokas, 2018), demikian juga dengan kepatuhan membayar pajak (Budiarso et al., 2019).

Berdasarkan Undang-Undang Nomor 28 Tahun 2009 pasal 1 angka 10 pajak daerah adalah kontribusi wajib kepada daerah yang terutang oleh orang pribadi atau badan yang bersifat memaksa berdasarkan Undang-Undang dengan tidak mendapatkan imbalan secara langsung dan digunakan untuk keperluan daerah bagi sebesar-besarnya kemakmuran rakyat. Sedangkan dalam pasal 1 angka 13 menyebutkan bahwa salah satu pajak daerah yang dapat 
dipungut oleh pemerintah adalah pajak kendaraan bermotor dan pajak kendaraan di atas air khususnya pajak kendaraan bermotor alat-alat berat atau alat-alat besar.

Menurut Peraturan Daerah Provinsi Sulawesi Utara Nomor 3 Tahun 2018 tentang perubahan kedua atas Peraturan Daerah Provinsi Sulawesi Utara Nomor 7 Tahun 2011 tentang Pajak Daerah pasal 1 angka 13 bahwa pengertian kendaraan bermotor alat-alat berat atau alat-alat besar adalah alat-alat yang dapat bergerak/berpindah tempat dan tidak melekat secara permanen. Menurut Peraturan Daerah Provinsi Sulawesi Utara Nomor 3 Tahun 2018 tentang perubahan kedua atas Peraturan Daerah Provinsi Sulawesi Utara Nomor 7 Tahun 2011 tentang Pajak Daerah pasal 1 angka 13, yang dimaksud kendaraan alat berat adalah kendaraan yang dipakai untuk suatu pekerjaan yang bersifat berat dan dalam lingkup yang besar, misalnya pengaspalan jalan, penggalian tanah, dan lain-lain, termasuk di dalamnya adalah forklift, buldozer, traktor, wheel loader, exavator, motor grader,asphalt finisher, rollers dan lain-lain.

\section{TINJAUAN PUSTAKA}

Menurut Hery (2014:1), akuntansi secara umum dapat didefinisikan sebagai sebuah sistem informasi yang memberikan laporan kepada para pengguna informasi akuntansi atau kepada pihak-pihak yang memiliki kepentingan (stakeholders) terhadap hasil kinerja dan kondisi perusahaan. Pajak adalah iuran kepada Negara (yang dapat dipaksakan) yang terutang oleh yang wajib membayarnya menurut peraturan-peraturan, dengan tidak mendapat prestasi kembali, yang langsung dapat ditunjuk, dan yang gunanya adalah untuk membiayai pengeluaran-pengeluaran umum berhubung tugas negara untuk menyelenggarakan pemerintahan (Mardiasmo, 2011:1). Sedangkan menurut Miller dan Oast (2012:3), pajak adalah sistem pemungutan wajib yang dikenakan untuk membiayai belanja publik.

Menurut Mardiasmo (2016:4), terdapat 2 fungsi pajak yaitu fungsi anggaran (budgetair) atau pajak sebagai sumber dana bagi pemerintah untuk membiayai pengeluaranpengeluarannya dan fungsi mengatur (regulerend) atau pajak sebagai alat untuk mengatur atau melaksanakan kebijaksanaan pemerintah dalam bidang sosial dan ekonomi. Menurut Sari (2013:40), pajak juga memiliki fungsi lain, yaitu fungsi stabilitas, fungsi redistribusi, dan fungsi demokrasi. Menurut Waluyo (2011:16), asas pemungutan pajak terdiri dari 3 asas yaitu asas tempat tinggal, asas kebangsaan dan asas sumber. Menurut Mardiasmo (2011:7), sistem pemungutan pajak terdiri dari beberapa sistem yaitu, official assessment system, self assessment system, dan withholding system.

Menurut Supramono dan Damayanti (2015:10), pajak dikelompokan menjadi tiga, yaitu sebagai berikut: (1) menurut golongannya, terdiri dari pajak langsung dan pajak tidak langsung; (2) menurut sifatnya, terdiri dari pajak subjektif dan pajak objektif; dan (3) menurut lembaga pemungutnya, terdiri dari pajak pusat dan pajak daerah. Pajak daerah terdiri dari pajak provinsi yang dipungut oleh pemerintah daerah tingkat I dan pajak kabupaten/kota yang dipungut oleh pemerintah daerah tingkat II.

Menurut Siregar (2015:31) dalam Assa et al. (2018), Pendapatan Asli Daerah menjadi sumber penerimaan yang diperoleh daerah dari sumber-sumber di wilayahnya sendiri yang diambil berdasarkan peraturan daerah. Pendapatan Asli Daerah (PAD) merupakan pendapatan daerah yang bersumber dari hasil pajak daerah, hasil retribusi daerah, hasil pengelolaan kekayaan daerah yang dipisahkan, dan lain-lain Pendapatan Asli Daerah yang sah, yang bertujuan untuk memberikan keleluasaan kepada daerah dalam menggali pendanaan dalam pelaksanaan otonomi daerah sebagai mewujudkan asas desentralisasi (UU Nomor 33 Tahun 2004).

Menurut Siahaan (2016:10), pajak daerah adalah pajak yang ditetapkan oleh pemerintah daerah dengan peraturan daerah, yang wewenang pemungutannya dilaksanakan oleh pemerintah daerah dan hasilnya digunakan untuk membiayai pengeluaran pemerintah 
daerah dalam melaksanakan penyelenggaraan pemerintahan dan pembangunan di daerah. Pengertian pajak daerah menurut Undang-Undang Nomor 28 Tahun 2009 tentang Pajak Daerah dan Retribusi Daerah, yaitu kontribusi wajib kepada daerah yang terutang oleh orang pribadi atau badan yang bersifat memaksa berdasarkan Undang-Undang, dengan tidak mendapatkan imbalan secara langsung dan digunakan untuk keperluan daerah bagi sebesarbesarnya kemakmuran rakyat. Dalam pasal 1 angka 13 Peraturan Daerah Provinsi Sulawesi Utara Nomor 3 Tahun 2018 tentang perubahan kedua atas Peraturan Daerah Provinsi Sulawesi Utara Nomor 7 Tahun 2011 tentang Pajak Daerah bahwa pengertian kendaraan bermotor alat-alat berat atau alat-alat besar adalah alat-alat yang dapat bergerak/berpindah tempat dan tidak melekat secara permanen. Alat berat merupakan salah satu kendaraan peralatan teknis berupa motor atau peralatan lainnya yang berfungsi mengubah suatu sumber daya energi tertentu menjadi gerak kendaraan. Mahmudi (2010:143) dalam Hebimisa et al. (2017) menyatakan bahwa kontribusi digunakan untuk mengetahui sejauh mana pajak daerah berkontribusi dalam penerimaan Pendapatan Asli Daerah dimana untuk menghitung kontribusi dapat menggunakan rumus berikut.

$$
\text { Kontribusi pajak alat berat }=\frac{\text { Realisasi pajak alat berat }}{\text { Realisasi penerimaan PAD }} \times 100 \%
$$

\section{METODE PENELITIAN}

Jenis penelitian yang digunakan dalam penelitian ini adalah jenis penelitian kualitatif. Penelitian ini adalah penelitian yang dilakukan melalui pengamatan untuk mendapatkan keterangan-keterangan terhadap suatu masalah tertentu serta untuk mendapatkan gambaran tentang perbandingan jumlah alat-alat berat dengan penerimaan pemungutan pajak dari tahun ke tahun dan kontribusinya sebagai salah satu sumber Pendapatan Asli Daerah (PAD) Provinsi Sulawesi Utara. Penelitian ini dilakukan di Badan Pendapatan Daerah Provinsi Sulawesi Utara Jalan 17 Agustus No. 67 Manado. Data kualitatif dalam penelitian ini meliputi seluruh informasi yang diperoleh dari hasil wawancara dengan subyek penelitian yaitu staf pegawai kantor di bagian pajak daerah terkait pemungutan pajak alat-alat berat dalam meningkatkan penerimaan Pendapatan Asli Daerah di Provinsi Sulawesi Utara serta kendala yang ditemui dalam pemungutan pajak alat berat. Data kuantitatif yang dibutuhkan dalam penelitian ini adalah data jumlah alat berat dan data penerimaan pajak alat berat di Provinsi Sulawesi Utara mulai dari tahun 2016-2018. Data berbentuk angka-angka yang dapat dihitung.

Sumber data primer dalam penelitian ini diperoleh langsung dari subjek penelitian dengan wawancara terkait jumlah alat berat dan penerimaan pajak alat berat dalam meningkatkan pendapatan asli daerah di Provinsi Sulawesi Utara dari aspek administrasi, personal (petugas), evaluasi dan pengawasan serta pemanfaatan hasil dan peningkatan penerimaan pajak alat berat dalam tiga tahun terakhir yaitu tahun 2016 sampai dengan tahun 2018 di Provinsi Sulawesi Utara. Data yang telah dikumpulkan kemudian dianalisis dan diproses lebih lanjut melalui pengamatan langsung dan dituangkan dalam catatan hasil wawancara yang bersumber dari pegawai di Badan Pendapatan Daerah Provinsi Sulawesi Utara. Sumber data primer adalah sumber data yang diperoleh atau dikumpulkan langsung oleh orang yang melakukan penelitian atau yang bersangkutan yang memerlukannya (Supardi, 2013:16). Penelitian ini menggunakan metode pengumpulan data dalam bentuk: wawancara, dan dokumentasi, dimana metode analisis data yang digunakan dalam penelitian ini adalah metode analisis deskriptif. 


\section{HASIL PENELITIAN DAN PEMBAHASAN}

\subsection{Hasil penelitian}

Data penelitian yang diperoleh dari Badan Pendapatan Daerah Provinsi Sulawesi Utara secara garis besar dapat dilihat dari Tabel 1 yang merupakan data target pajak alat berat, realisasi pajak alat berat dan realisasi Pendapatan Asli Daerah tahun 2016-2018, yang berhubungan dengan permasalahan yang sedang diteliti:

Tabel 1. Target pajak alat berat, realisasi penerimaan pajak alat berat dan realisasi PAD tahun 2016-2018

\begin{tabular}{lccr}
\hline $\begin{array}{c}\text { Tahun } \\
\text { Anggaran }\end{array}$ & $\begin{array}{c}\text { Target Pajak Alat } \\
\text { Berat }\end{array}$ & Realisasi Pajak Alat Bera & Realisasi PAD \\
\hline 2016 & Rp. 125.000 .000 & Rp. 245.518.667 & Rp. 981.044 .550 .486 \\
2017 & Rp. 270.154.260 & Rp. 325.372.596 & Rp. 1.146 .674 .827 .814 \\
2018 & Rp. 153.994.500 & Rp. 23.861.300 & Rp.1.265.412.698.030 \\
\hline
\end{tabular}

Sumber: Badan Pendapatan Daerah Provinsi Sulawesi Utara, 2019

Data jumlah alat berat dari tahun ke tahun tidak mengalami perubahan baik pengurangan maupun pertambahan jumlah alat berat/besar. Tabel 2 menunjukkan data jumlah alat berat/besar di provinsi Sulawesi Utara dalam 3 (tiga) tahun terakhir yaitu tahun 2016-2018 yang telah diperoleh dariBadan Pendapatan Daerah Provinsi Sulawesi Utara.

Tabel 2. Data jumlah alat berat di Provinsi Sulawesi Utara tahun 2016-2018

\begin{tabular}{lc}
\hline Unit Pelaksana Teknis Daerah & Data jumlah alat berat di Provinsi Sulawesi Utara \\
\hline Manado & 49 \\
Tahuna & 4 \\
Talaud & 9 \\
Tondano & 7 \\
Bitung & 12 \\
Airmadidi & 84 \\
Bolmong & 5 \\
Boltim & 6 \\
Bolsel & 5 \\
Amurang & 4 \\
Tomohon & 1 \\
Sitaro & - \\
Bolmut & - \\
Mitra & - \\
Kotamobagu & - \\
\hline Total & $\mathbf{1 8 6}$ \\
\hline
\end{tabular}

Sumber: Badan Pendapatan Daerah Provinsi Sulawesi Utara, 2019

Penerimaan pajak alat berat/besar untuk tiga tahun terakhir ini juga mengalami fluktuasi. Hal ini dapat dilihat dari rekapitulasi penerimaan atau realisasi pajak alat berat/besar di provinsi Sulawesi Utara dalam 3 (tiga) tahun terakhir yaitu tahun 2016-2018 yang telah diperoleh peneliti yang disajikan dalam tabel berikut ini: 
Tabel 3. Rekapitulasi penerimaan/realisasi pajak alat berat/besar tahun 2016-2018

\begin{tabular}{|c|c|c|c|c|c|c|c|}
\hline \multirow{2}{*}{ No } & \multirow{2}{*}{ SAMSA } & \multicolumn{2}{|c|}{ Tahun 2016} & \multicolumn{2}{|c|}{ Tahun 2017} & \multicolumn{2}{|c|}{ Tahun 2018} \\
\hline & & Unit & $\mathbf{R p}$ & Unit & $\mathbf{R p}$ & Unit & $\mathbf{R p}$ \\
\hline 1 & Manado & 30 & 50.169 .100 & 40 & 55.685 .800 & - & \\
\hline 2 & Tahuna & - & - & 2 & 1.745 .700 & 2 & 2.357 .000 \\
\hline 3 & Talaud & - & - & - & - & - & - \\
\hline 4 & Tondano & 1 & 2.365 .000 & 5 & 14.814 .800 & 1 & 3.830 .500 \\
\hline 5 & Bitung & - & - & 7 & 23.028 .200 & - & - \\
\hline 6 & Airmadidi & 34 & 192.984 .567 & 45 & 207.125.196 & - & - \\
\hline 7 & Bolmong & - & - & - & - & - & - \\
\hline 8 & Boltim & - & - & - & - & - & - \\
\hline 9 & Bolsel & - & - & - & - & - & - \\
\hline 10 & Amurang & - & - & 8 & 22.972 .900 & 16 & 17.673 .800 \\
\hline 11 & Tomohon & - & - & - & - & - & - \\
\hline 12 & Sitaro & - & - & - & - & - & - \\
\hline 13 & Bolmut & - & - & - & - & - & - \\
\hline 14 & Mitra & - & - & - & - & - & - \\
\hline \multirow[t]{2}{*}{15} & Kotamobagu & - & - & - & - & - & - \\
\hline & TOTAL & 65 & Rp.245.518.667 & 107 & Rp.325.372.596 & 19 & Rp.23.861.300 \\
\hline
\end{tabular}

Hasil penghitungan kontribusi pajak alat berat/alat besar dalam meningkatkan Pendapatan Asli Daerah di provinsi Sulawesi Utara untuk tahun 2016-2018 dapat dilihat pada tabel 4 dibawah ini:

Tabel 4. Kontribusi pajak alat berat/alat besar dalam meningkatkan Pendapatan Asli Daerah pemerintah Provinsi Sulawesi Utara tahun 2016-2018

\begin{tabular}{lcrr}
\hline $\begin{array}{c}\text { Tahun } \\
\text { Anggaran }\end{array}$ & $\begin{array}{c}\text { Realisasi Penerimaan } \\
\text { Pajak Alat Berat/Alat } \\
\text { Besar }\end{array}$ & $\begin{array}{c}\text { Pendapatan Asli } \\
\text { Daerah }\end{array}$ & $\begin{array}{c}\text { Kontribusi Pajak } \\
\text { Alat Berat/Alat } \\
\text { Besar (\%) }\end{array}$ \\
\hline 2016 & Rp. 245.518.667 & Rp. 981.044 .550 .486 & 0.25 \\
2017 & Rp. 325.372 .596 & Rp. 1.146 .674 .827 .814 & 0.28 \\
2018 & Rp. 23.861.300 & Rp. 1.265 .412 .698 .030 & 0.018 \\
\hline
\end{tabular}

Sumber: Data olahan, 2019

Tahun 2016

$$
\begin{array}{ll}
=\frac{245.518 .667}{981.044 .550 .486} \times & 100 \% \\
=0.25 \% &
\end{array}
$$

Tahun 2017

$$
\begin{aligned}
& =\frac{325.372 .596}{1.146 .674 .827 .814} \mathrm{X} \\
& =0.28 \%
\end{aligned}
$$
$100 \%$

Tahun 2018

$$
\begin{aligned}
& =\frac{23.861 .300}{1.265 .412 .698 .030} \mathrm{X} \\
& =0.018 \%
\end{aligned}
$$

$100 \%$ 


\subsection{Pembahasan}

Tabel 5 menunjukkan bahwa rekapitulasi perbandingan penerimaan pajak alat berat/besar dan jumlah alat berat/besar di Provinsi Sulawesi Utara dalam 3 (tiga) tahun terakhir yaitu tahun 2016-2018. Jumlah yang terdaftar dengan jumlah yang membayar pajak alat berat/besar memiliki perbandingan yang tidak seimbang dari tahun ke tahun. Dengan rata-rata jumlah penerimaan atau realisasi pajak alat berat/besar 3 (tiga) tahun terakhir adalah sebesar Rp. 198.250.854. Hal ini terjadi karena masih banyak pengusaha atau wajib pajak yang memiliki alat berat/besar yang tidak taat pajak dengan tidak membayar pajak alat berat/besar yang dimiliki.

Tabel 5. Perbandingan jumlah alat-alat berat dengan penerimaan pemungutan pajak dari tahun 2016-2018

\begin{tabular}{llrrrrrrr}
\hline \multirow{2}{*}{ NO SAMSAT } & \multirow{2}{*}{ Jumlah } & \multicolumn{2}{c}{ Tahun 2016 } & \multicolumn{2}{c}{ Tahun 2017 } & \multicolumn{2}{c}{ Tahun 2018 } \\
\cline { 3 - 8 } & & & Unit & \multicolumn{1}{c}{ Rupiah } & Unit & \multicolumn{1}{c}{ Rupiah } & Unit & Rupiah \\
\hline 1 & Manado & 49 & 30 & 50.169 .100 & 40 & 55.685 .800 & - & - \\
2 & Tahuna & 4 & - & - & 2 & 1.745 .700 & 2 & 2.357 .000 \\
3 & Talaud & 9 & - & - & - & - & - & - \\
4 & Tondano & 7 & 1 & 2.365 .000 & 5 & 14.814 .800 & 1 & 3.830 .500 \\
5 & Bitung & 12 & - & - & 7 & 23.028 .200 & - & - \\
6 & Airmadidi & 84 & 34 & 192.984 .567 & 45 & 207.125 .196 & - & - \\
7 & Bolmong & 5 & - & - & - & - & - & - \\
8 & Boltim & 6 & - & - & - & - & - & - \\
9 & Bolsel & 5 & - & - & - & - & - & - \\
10 & Amurang & 4 & - & - & - & 22.972 .900 & 16 & 17.673 .800 \\
11 & Tomohon & 1 & - & - & - & - & - & - \\
12 & Sitaro & - & - & - & - & - & - & - \\
13 & Bolmut & - & - & - & - & - & - & - \\
14 & Mitra & - & - & - & - & - & - & - \\
15 & Kotamobagu & - & - & - & - & - & - & - \\
\hline \multicolumn{2}{c}{ TOTAL } & $\mathbf{1 8 6}$ & $\mathbf{6 5}$ & $\mathbf{2 4 5 . 5 1 8 . 6 6 7}$ & $\mathbf{1 0 7} \mathbf{3 2 5 . 3 7 2 . 5 9 6}$ & & $\mathbf{2 3 . 8 6 1 . .}$ \\
\hline
\end{tabular}

Sumber: Badan Pendapatan Daerah Provinsi Sulawesi Utara, 2019

Tabel 6 menunjukkan kontribusi pajak alat berat/besar dalam meningkatkan pendapatan asli daerah Provinsi Sulawesi Utara terbesar pada tahun 2017 sebesar $0.28 \%$ dan terendah pada tahun 2018 sebesar $0.018 \%$. Hal ini menunjukkan rata-rata persentase kontribusi alat berat/besar dalam meningkatkan pendapatan asli daerah provinsi Sulawesi Utara tahun 2016-2018 tahun sangat kurang berkontribusi yaitu sebesar 0.18\%.

Tabel 6. Kontribusi pajak alat berat/besar dalam meningkatkan Pendapatan Asli Daerah Provinsi Sulawesi Utara tahun 2016-2018

\begin{tabular}{crrrr}
\hline Tahun & $\begin{array}{c}\text { Realisasi Pajak Alat } \\
\text { Berat }\end{array}$ & \multicolumn{1}{c}{ Realisasi PAD } & Persentase & Kriteria \\
\hline 2016 & 245.518 .667 & 981.044 .550 .486 & 0.25 & Sangat kurang \\
2017 & 325.372 .596 & 1.146 .674 .827 .814 & 0.28 & Sangat kurang \\
2018 & 23.861 .300 & 1.265 .412 .698 .030 & 0.018 & Sangat kurang \\
\hline & Rata-rata & & $\mathbf{0 . 1 8 \%}$ & Sangat kurang \\
\hline
\end{tabular}

Sumber: Data olahan, 2019

Hasil wawancara dengan Bapak Ocvy Leke selaku Kepala Bidang Perencanaan dan Pengembangan di Badan Pendapatan Daerah Provinsi Sulawesi Utara, pemungutan pajak alat-alat berat atau besar terdapat berbagai kendala yang harus dihadapi oleh pemerintah. 
Hambatan atau kendala-kendala tersebut dapat diatasi dengan upaya-upaya optimalisasi yang dapat dilakukan oleh pemerintah yang ditunjukkan dalam Tabel 7 dibawah ini:

Tabel 7. Kendala dan upaya pemerintah yang dihadapi oleh pemerintah dalam pemungutan pajak alat berat/besar di provinsi Sulawesi Utara pada tahun 2016-2018

No Kendala $\quad$ Upaya Penyelesaian

1. Pemungutan pajak alat-alat berat ini Setiap tahunnya pihak pemerintah daerah harus tergolong sangat susah karena alat berat mendata perusahaan atau pengusaha yang sendiri tidak menggunakan jalan umum, menggunakan alat berat dan jumlah alat berat yang alat berat lebih banyak berada di tempat- dimiliki sehingga mempermudah untuk pemungutan tempat terpencil jadi pemerintah sulit pajak alat berat itu sendiri.

untuk mendata alat berat tersebut.

2. Ada beberapa yang tergabung dalam Persiapan penyusunan regulasi yang baru tentang asosiasi pemilik dan pengguna alat berat yang mengajukan gugatan atau keberatan atas pemungutan pajak alat berat kepada Mahkamah Konstitusi dan menganggap alat berat bukan termasuk ke dalam kendaraan bermotor sehingga tidak di pungut pajak.

3. Adanya beberapa pengusaha yang sengaja menghindar jika dilakukan pemungutan juga menjadi kendala dalam pemungutan alat berat.

4. Kurangnya sanksi yang tegas dari Pemerintah seharusnya memberikan sanksi yang pemerintah juga memengaruhi tegas bagi perusahaan alat berat yang tidak kesadaran wajib pajak untuk membayar pajak. Misalnya menyita alat-alat berat melaporkan jumlah alat berat yang atau larangan beroperasi bagi wajib pajak yang dimiliki. tidak membayar pajak alat-alat berat tersebut.

Sumber: Data olahan, 2019

Dari hasil wawancara diatas dapat disimpulkan bahwa terjadinya kesalahpahaman dalam komunikasi antara wajib pajak dan pihak pemerintah daerah sehingga menurut pihak wajib pajak menyatakan bahwa alat berat sudah tidak dapat dikenakan pajak namun menurut pemerintah daerah menyatakan bahwa alat berat masih dipungut pajak namun pajak alat berat akan dipisahkan dengan pajak kendaraan bermotor. Dan saat ini pihak pemerintah daerah sedang membahas mengenai peraturan baru untuk pengenaan pajak alat berat.

\section{KESIMPULAN DAN SARAN}

\subsection{Kesimpulan}

Berdasarkan hasil penelitian dan pembahasan mengenai analisis perbandingan jumlah alat-alat berat dengan penerimaan pemungutan pajak dari tahun ke tahun dan analisis kontribusi pajak alat-alat berat dalam meningkatkan penerimaan pendapatan asli daerah di Provinsi Sulawesi Utara, maka dapat diambil kesimpulan sebagai berikut:

1. Jumlah yang terdaftar dengan jumlah yang membayar pajak alat berat atau besar memiliki perbandingan yang tidak seimbang dari tahun ke tahun. Pada tahun 2017 terjadi kenaikan sekitar 32\% sedangkan pada tahun 2018 terjadi penurunan sekitar 92\% penerimaan pajak alat berat. Dengan rata-rata jumlah penerimaan atau realisasi pajak alat berat atau besar 3 (tiga) tahun terakhir adalah sebesar Rp.198.250.854. Hal ini terjadi karena masih banyak pengusaha atau wajib pajak yang memiliki alat berat/besar yang tidak taat pajak dengan tidak membayar pajak alat berat atau besar yang mereka miliki. 
2. Persentase kontibusi pajak alat berat terhadap penerimaan pendapatan asli daerah setiap tahunnya mengalami fluktuasi. Hal ini dikarenakan jumlah penerimaan pendapatan asli daerah lebih besar dari pada penerimaan pajak alat-alat berat.

3. Kriteria kontribusi pajak alat berat terhadap penerimaan pendapatan asli daerah dari tahun 2016 sampai dengan 2018 masih dalam kategori yang sangat kurang. Rata-rata kontribusi pajak alat berat dari tahun 2016 sampai dengan 2018 hanya sebesar $0.18 \%$ hal ini menunjukan kriteria yang sangat kurang berkontribusi dalam meningkatkan penerimaan pendapatan asli daerah.

4. Penerimaan pajak alat berat sangat kurang berkontribusi karena kurang adanya kesadaran dari pengusaha alat berat untuk ikut berpartisipasi dalam pembangunan daerah, karena banyaknya kendala-kendala yang dialami pemerintah daerah dalam upaya pemungutan pajak alat berat.

5. Terjadinya kesalahpahaman dalam komunikasi antara wajib pajak dan pihak pemerintah daerah sehingga menurut pihak wajib pajak menyatakan bahwa alat berat sudah tidak dapat dikenakan pajak namun menurut pemerintah daerah menyatakan bahwa alat berat masih dipungut pajak akan tetapi pajak alat berat akan dipisahkan dengan pajak kendaraan bermotor.

\subsection{Saran}

Berdasarkan hasil penelitian, saran yang dapat diberikan pada Badan Pendapatan Daerah Provinsi Sulawesi Utara adalah:

1. Badan Pendapatan Daerah Provinsi Sulawesi Utara seharusnya lebih meningkatkan pelaksanaan pemungutan terhadap pajak alat-alat berat.

2. Pemerintah daerah setiap tahunnya harus melakukan pendataan terhadap perusahaan atau pengusaha yang menggunakan alat berat dan jumlah alat berat yang dimiliki.

3. Melakukan sosialisasi peraturan yang mengatur tentang pajak alat berat terhadap pengusaha alat berat yang belum mengetahui peraturan serta tarif alat berat.

4. Memberikan sanksi yang tegas bagi perusahaan alat berat yang tidak membayar pajak.

5. Melakukan sosialisasi yang mendalam mengenai peraturan pemisahan pajak alat berat yang terbaru.

\section{DAFTAR PUSTAKA}

Assa, P. G., Manossoh, H., \& Mawikere, L. (2018). Analisis kontribusi pajak kendaraan bermotor terhadap Pendapatan Asli Daerah Provinsi Sulawesi Utara periode (20132017). Going Concern: Jurnal Riset Akuntansi, 13(4), 730-733. https://doi.org/10.32400/gc.13.04.21866.2018.

Budiarso, N. S., Pontoh, W., \& Wokas, H. R. N., (2019). Ipteks penghitungan pajak penghasilan terutang berdasarkan PP nomor 23 tahun 2018 di Kelurahan Malendeng Kecamatan Paal 2 Kota Manado. Jurnal Ipteks Akuntansi bagi Masyarakat, 3(1), 916. https://doi.org/10.32400/jiam.3.1.2019.23303.

Buntuan, D., \& Wokas, H. (2018). Ipteks pelaksanaan pemungutan pajak air permukaan pada Cabang Pelayanan Pendapatan Daerah Wilayah Kabupaten Bandung Barat. Jurnal Ipteks Akuntansi bagi Masyarakat, 02(02), 146-150. https://doi.org/10.32400/jiam.2.02.2018.21715

Darwin. (2010). Pajak daerah dan retribusi daerah. Jakarta: Mitra Wacana Media.

Hebimisa, M. T., Sondakh, J. J., \& Wangkar, A. (2017). Analisis efektivitas dan kontribusi penerimaan pajak reklame, Pajak Bumi Bangunan terhadap Pendapatan Asli Daerah Kabupaten Siau Tagulandang Biaro. Going Concern: Jurnal Riset Akuntansi, 12(2). 1021-1032. https://doi.org/10.32400/gc.12.2.18529.2017 
Hery. (2014). Akuntansi perpajakan. Jakarta: Grasindo.

Mardiasmo. (2011). Perpajakan, Edisi revisi 2011. Yogyakarta: Andi.

Mardiasmo. (2016). Perpajakan, Edisi terbaru 2016. Yogyakarta: Andi.

Miller, A., \& Oast, L. (2012). Principle of International taxation. Bloomsbury Professional.

Peraturan Daerah Provinsi Sulawesi Utara Nomor 3 Tahun 2018 tentang Perubahan Kedua Atas Peraturan Daerah Provinsi Sulawesi Utara Nomor 7 Tahun 2011 tentang Pajak Daerah.

Sari, D. (2013). Konsep dasar perpajakan. Bandung: Refika Aditama.

Siahaan, M, P. (2016). Pajak daerah dan retribusi daerah, Edisi revisi. Jakarta: PT Raja Grafindo Persada.

Supardi. (2013). Aplikasi statistika dalam penelitian: Konsep statistika yang lebih komprehensif. Jakarta: Change Publication.

Supramono, \& Damayanti, T. W. (2015). Perpajakan Indonesia: Mekanisme dan perhitungan.Yogyakarta: Andi.

Undang-Undang Republik Indonesia Nomor 28 Tahun 2009 tentang Pajak Daerah dan Retribusi Daerah. Lembaran Negara Republik Indonesia Tahun 2009 Nomor 5049.

Undang-Undang Republik Indonesia Nomor 33 Tahun 2004 tentang Perimbangan Keuangan Antara Pemerintah Pusat dan Pemerintahan Daerah. Lembaran Negara Republik Indonesia Tahun 2004 Nomor 126.

Santoso, A. (2020). Ipteks perhitungan potensi Pendapatan Asli Daerah (PAD) di Kota Semarang. Jurnal Ipteks Akuntansi bagi Masyarakat, 4(1), 1-7. https://doi.org/10.32400/jiam.4.1.2020.26921.

Waluyo. (2011). Perpajakan Indonesia. Jakarta: Salemba Empat.

Wulandari, P. A., \& Iryanie, E. (2018). Pajak daerah dalam pendapatan asli daerah. Cetakan Pertama. Yogyakarta: Deepublish. 